\title{
Analysis of the right and left ventricular images during one cardiac cycle by a simultaneous biplane first-pass radionuclide ventriculography
}

山形大学医学部附属病院放射線部

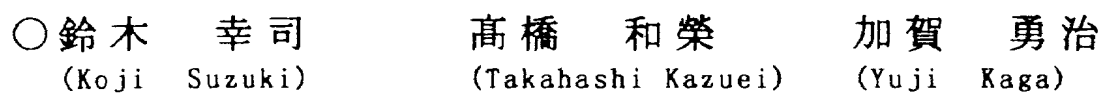

【目的】テクネ心㳙血流製剤の導入により、心䈈虚血の検出や心筋 viability の判定とともに、心機能の同時 評価が可能になった。また、多検出器型ガンマカメラは同時に多方向からの dynamic データ収集が行える。そこ で私たちの施設では、より簡便に心筋壁運動を観察するため、日常の心筇血流 SPECT 検査時に同時 2 方向 first pass 法を施行し、RV·LVの 1 心周期画像 (first pass image)の作成と心筋壁運動の解析を試みた。

【方法および結果】MULTISPECT3(シーメンス)は、検出器どうしの開角度が60度に限定される、合計1000f rame 以上の収集が出来ない、コリメータ (LEHR)が低感度でcount rateが足りない、1ist mode収集が出来ないなどの 制約がある。そのため、以下の方法でfirst pass法を施行した。

MULTISPECT3 の 2 検出器を被験者の右前斜位 30 度と左側面に配置し、右肘静脈また流右顠静脈より99-Tc一MIBI 1110MBq を急速静注する。収集条件は 32 x $32 \mathrm{matrix}, 1 \mathrm{f} / 50 \mathrm{msec}, 25 \mathrm{sec}$ 収集である。データ処理には ICON(シ

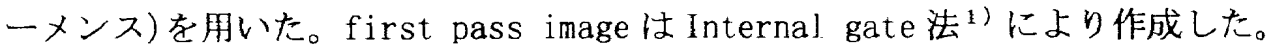

Internal gate 法は、まずRV・LVに設定したROI から time activity curve を作成する。次にRV・LVそれぞれ に変化分を強調させた time activity curveより、RV・LVの範囲を選択する。さらに 1 心拍毎にEDを選択し、ED の frame を確定する。確定した $\mathrm{ED}$ を基準に同位相の画像を数 frame（選択した心拍数分）加算 し、RV・LV について first pass image が出来る。（Fig.1）この first pass image から心筋壁運 動の解析を行った。

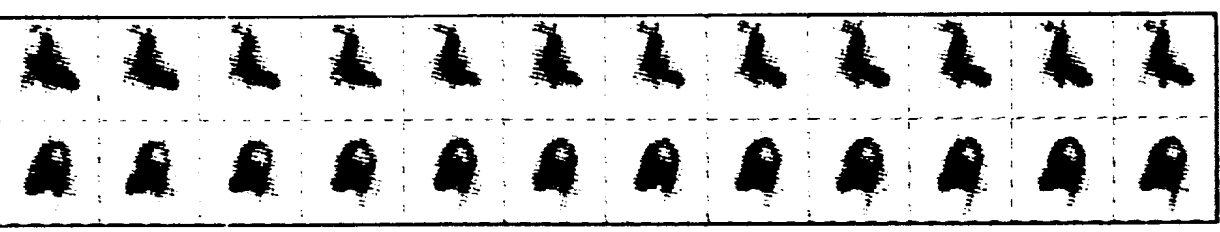

Fig. 1 first pass image

EF (ejection fraction) は逐次定数減算法 ${ }^{2}$ により BG 存除去し固定 ROI 法にて求めた。 逐次定数减算法で姏理した first passのデータは、overlap curve から離れていくにし たがい直線になる。そこで、直線部と overlap curve の count との交点を BG の值とし た。（Fig. 2) 非線形フィルタ処理より操作が簡単心処理速度も速いためこの方法を用い ることにした。

心笳壁運動は、画像どうしを演算して表示 (EF ミmage)することにより、視覚的に把

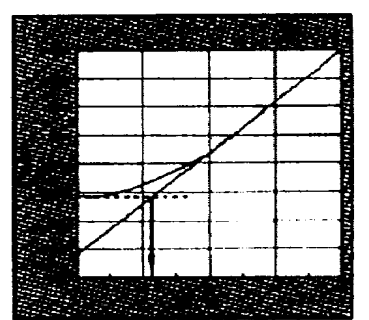

Fig. 2 ES shift data 握できる。（Fig. 3）

EF の值は、同時期の LVG と比較し た。（Fig. 4）ほとんどが急性心筋梗 塞の症例であることを考慮すれば、 相関に問題はない。

【まとめ】同時 2 方向 first pass 法は、心機能評価と心觔血流 SPECT が 1 回の R I 投与だけで可能なため、 被検者の負担を堿らすことができる。 さらに、心能壁運動が cine mode で同 時に 2 方向から観察できるため、従来

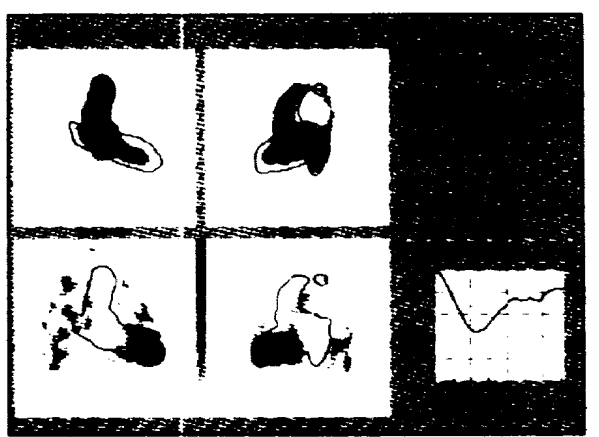

Fig. 3 first passの結果表示

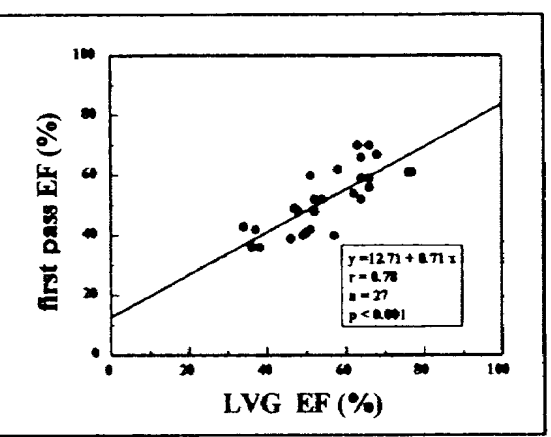

Fig. 4 first pass EF vs LVG EF

の右前斜位、左前斜位単独に比べ情報量が増大し盲点を少なくすることができる。

しかし、コリメータの感度が低いため、テクネ心筋血流製剤を $1110 \mathrm{MBq}$ 必要とした。

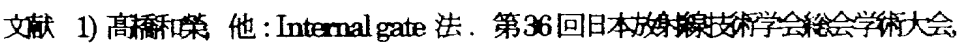

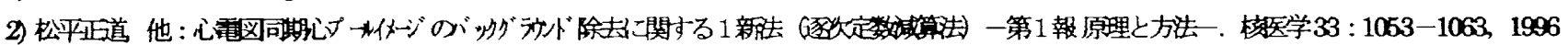

